\title{
FAST REACTOR SYSTEMS FOR SPACE POWER
}

\author{
Carl E. Johnson \\ U.S. Atomic Energy Commission \\ Washington, D.C.
}

\begin{abstract}
It appears that tens-of-kilowatts of electric power will be needed in space in the 1970's and hundreds-of-kilowatts in the 1980's. The Atomic Energy Commissions' reactor space power development program to meet these needs emphasizes three reactor concepts: the zirconium hydride thermal reactor for use with thermoelectric or dynamic conversion for the tens-of-kilowatts range in the 1970's, and the thermionic and advanced liquid metal cooled reactors for use with a variety of power conversion systems by around 1980. The paper discusses the development objectives of the space power reactor program, and describes an irradiation capsule and a liquid metal corrosion capsule which might be useful in other fast reactor projects.
\end{abstract}

\section{INTRODUCTION}

As we make use of our near-earth space capabilities and further explore the solar system, increasing amounts of electric power will be needed. As shown in Figure 1 , we expect that long-lived space power supplies in the tensof-kilowatts range will be needed during the 1970's, and that hundreds-ofkilowatts will be needed in the $1980^{\prime} \mathrm{s} .1$ At these power levels, reactor power systems are attractive.

The objectives of the Atomic Energy Commission's space power reactor development program to meet these anticipated needs are illustrated in Figure 2. For the tens-of-kilowatts range in 1970's, we are developing a zirconium hydride thermal reactor. This reactor can be used with thermoelectric power conversion to provide 10 to $25 \mathrm{KWe}$ in the early to mid 1970's. This same reactor can be used with NASA's mercury Rankine cycle, SNAP-8 system and possibly with Brayton or organic Rankine cycle power conversion when they are developed to provide up to $100 \mathrm{KWe}$.

The second range of power shown on Figure 2 illustrates where fast reactors are expected to play a role. This is in the 50-300 KW range during the 1980's. These advanced power plants are intended for use as advanced secondary power sources and for unmanned electric propulsion. 


\section{DISCLAIMER}

This report was prepared as an account of work sponsored by an agency of the United States Government. Neither the United States Government nor any agency Thereof, nor any of their employees, makes any warranty, express or implied, or assumes any legal liability or responsibility for the accuracy, completeness, or usefulness of any information, apparatus, product, or process disclosed, or represents that its use would not infringe privately owned rights. Reference herein to any specific commercial product, process, or service by trade name, trademark, manufacturer, or otherwise does not necessarily constitute or imply its endorsement, recommendation, or favoring by the United States Government or any agency thereof. The views and opinions of authors expressed herein do not necessarily state or reflect those of the United States Government or any agency thereof. 


\section{DISCLAIMER}

Portions of this document may be illegible in electronic image products. Images are produced from the best available original document. 


\section{SPACE ELECTRIC POWER NEEDS}

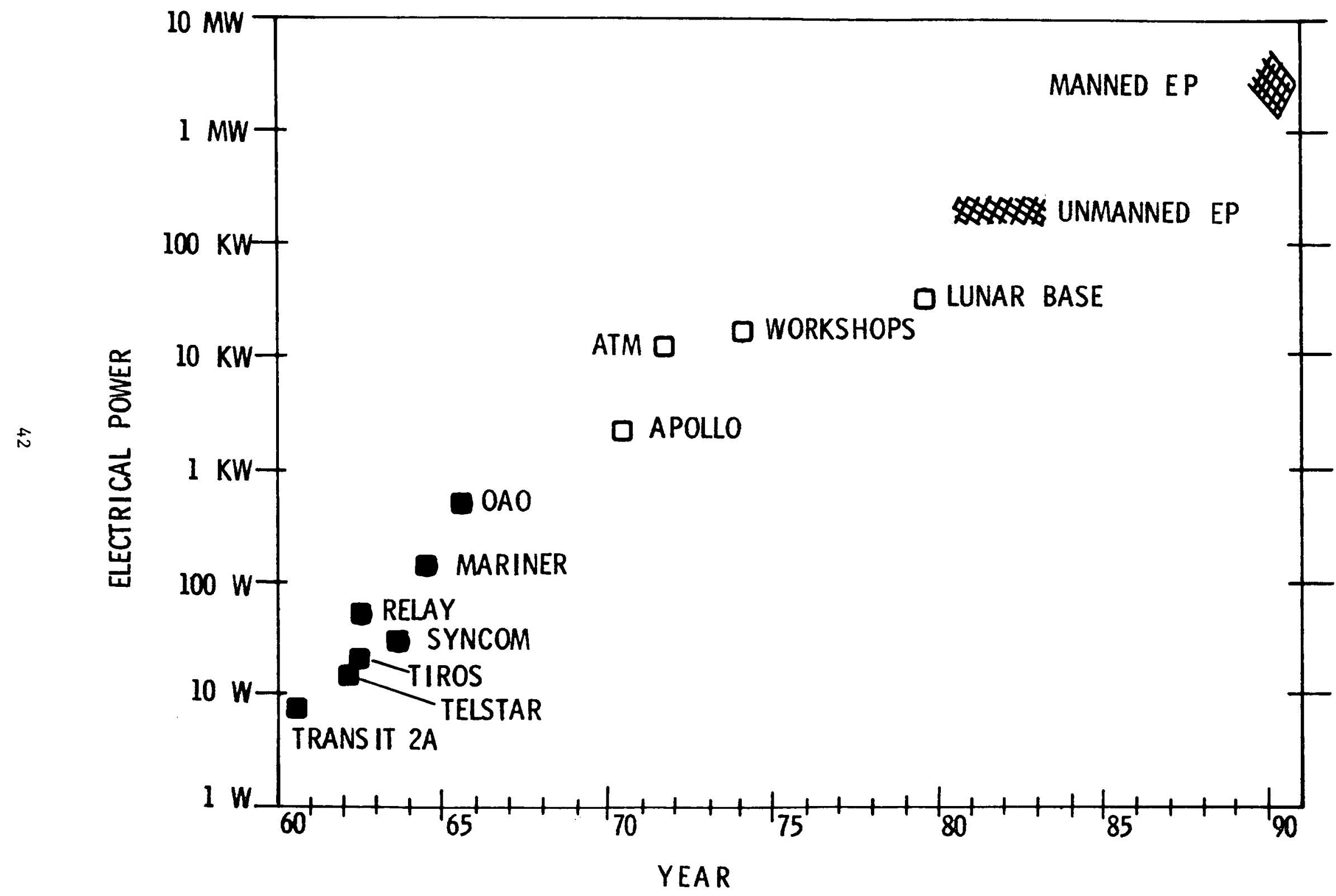

38 SEPO- 504 

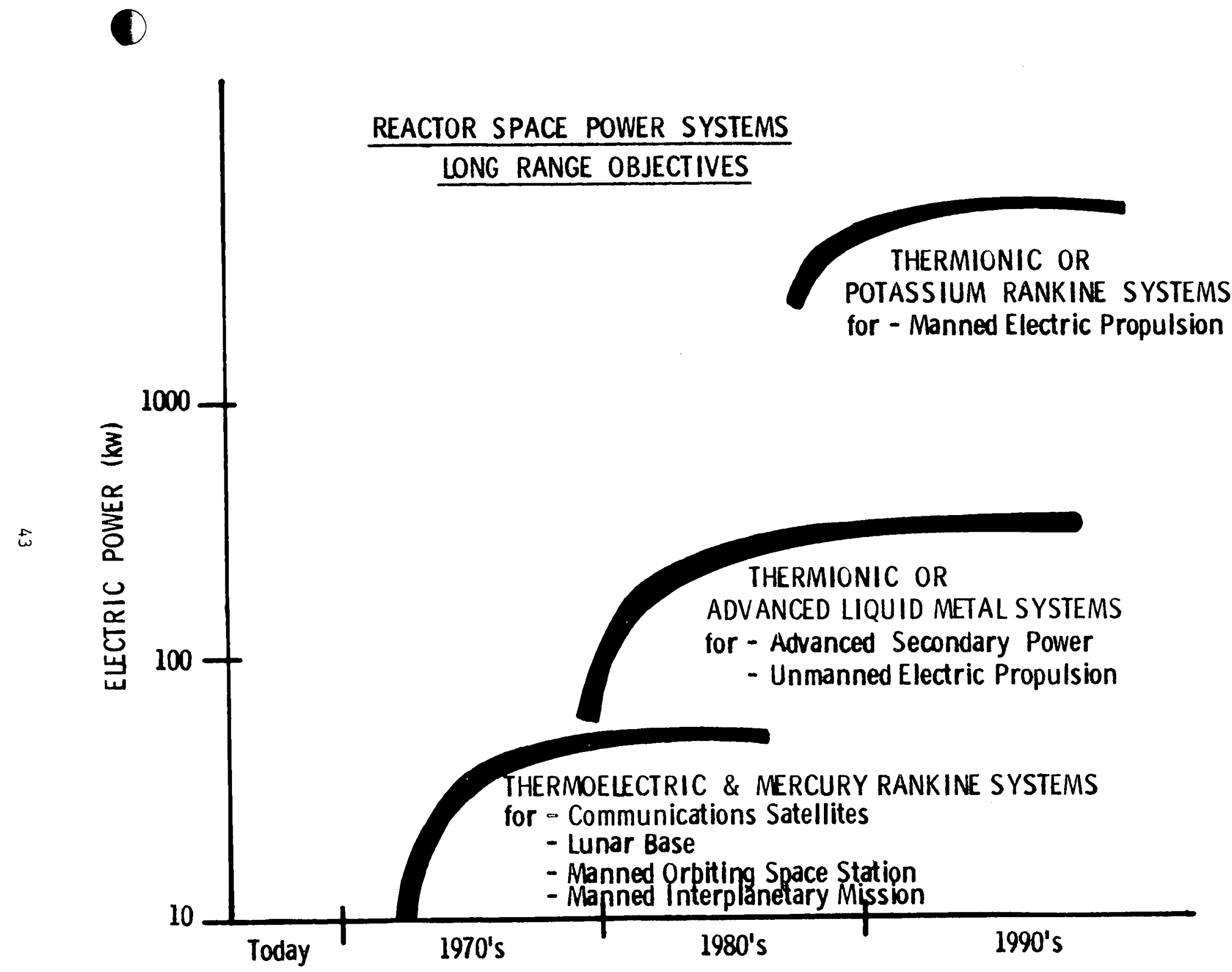
The third category of reactor power systems is in the megawatt range for manned electric propulsion in the late 1980's or 1990's.

Our approach to developing the advanced, i.e., fast reactors, is shown in Figure 3. The initial objective for the advanced reactors is to develop a 50$300 \mathrm{KW}$ power plant for secondary power and unmanned electric propulsion. In addition, we want to use this technology as a stepping stone to the megawattrange power plants. The long term objectives for megawatt-range systems is for manned electric propulsion. Therefore, the power plant concepts which we plan to develop at the 50-300 KWe range for the 1980's should have the performance potential for reaching very low specific weight. These two advanced reactor concepts are the thermionic reactor and the advanced liquid metal cooled reactor primarily for use with a potassium Rankine cycle.

\section{PERFORMANCE OF ALTERNATE POWER SYSTEMS}

There are two basic reasons why fast reactors have been selected for primary emphasis in our advanced reactor program. These are: requirements for high energy densities and high temperatures. These temperatures for the advanced reactors must be a sufficiently large increase over the $1300^{\circ} \mathrm{F}$ zirconium hydride reactors to make the advanced technology worth working on. In order to achieve high energy density at these temperatures without excessive fuel burnup, most of the core volume should be composed of fuel such as $\mathrm{UO}_{2}$, UN or $\mathrm{UC}$.

The incentive for high temperatures for space power plants is illustrated in Figure 4. This graph ${ }^{2}$ shows net specific radiator area required to reject waste heat from the power plant cycle, (i.e., total radiator area including power conditioning divided by net conditioned power output) as a function of fuel element surface temperatures in the reactor.* Figure 4 shows a clear trend towand reduced radiator area as the cycle top temperature goes up. This occurs because in order to increase the radiator temperature and still maintain a reasonable cycle efficiency the cycle top temperature must also go up. Figure 4 also shows the approximate temperature objectives of the three reactors which the AEC is developing. These are: the zirconium hydride reactor with a $1300^{\circ} \mathrm{F}$ coolant. outlet temperature, the advanced liquid metal cooled reactor with a coolant outlet temperature around $2200^{\circ} \mathrm{F}$, and the in-core thermionic reactor operating with an emitter-clad temperature over $3000^{\circ} \mathrm{F}$, but with a coolant temperature around $1300^{\circ} \mathrm{F}$.

Reactor energy density is important because reactor size affects the shield weight for given mission constraints. Figure 5,3 for example, shows an approximate relationship between reactor core volume and fuel volume fraction. "The

\footnotetext{
*Radiators are assumed radiate to a sink temperature of $-20^{\circ} \mathrm{F}$ with a product of (emittance) ( fin effectiveness) of 0.81 . Power conditioning is assumed to be 85 percent efficient for the direct-current thermoelectric and thermionic powerplants and 90 percent efficient for turboalternator systems. Power conditioning waste heat is assumed to be rejected at $100^{\circ} \mathrm{F}$.

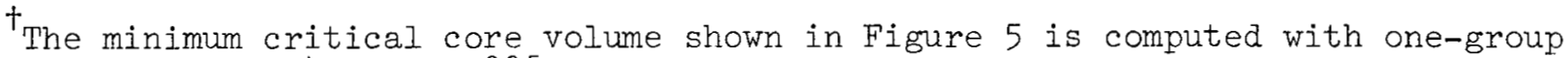
cross sections ${ }^{4}$ for a $\mathrm{U}^{235}$ fueled reactor, and assumes a two to three inch reflector savings.
} 


\section{ADVANCED REACTOR DEVELOPMENT APPROACH}

EARLY OBJECTIVES

- 50-300 KW FOR SECONDARY POWER AND UNMANNED

ELECTRIC PROPULSION

- technologr as a stepping stone to higher power

LONG TERM OBJECTIVES

- MEgawatts for manNed electric propulsion

- VERY LOW SYSTEM WEIGHT 
RADIATOR AREA VS. FUEL TEMPERATURE

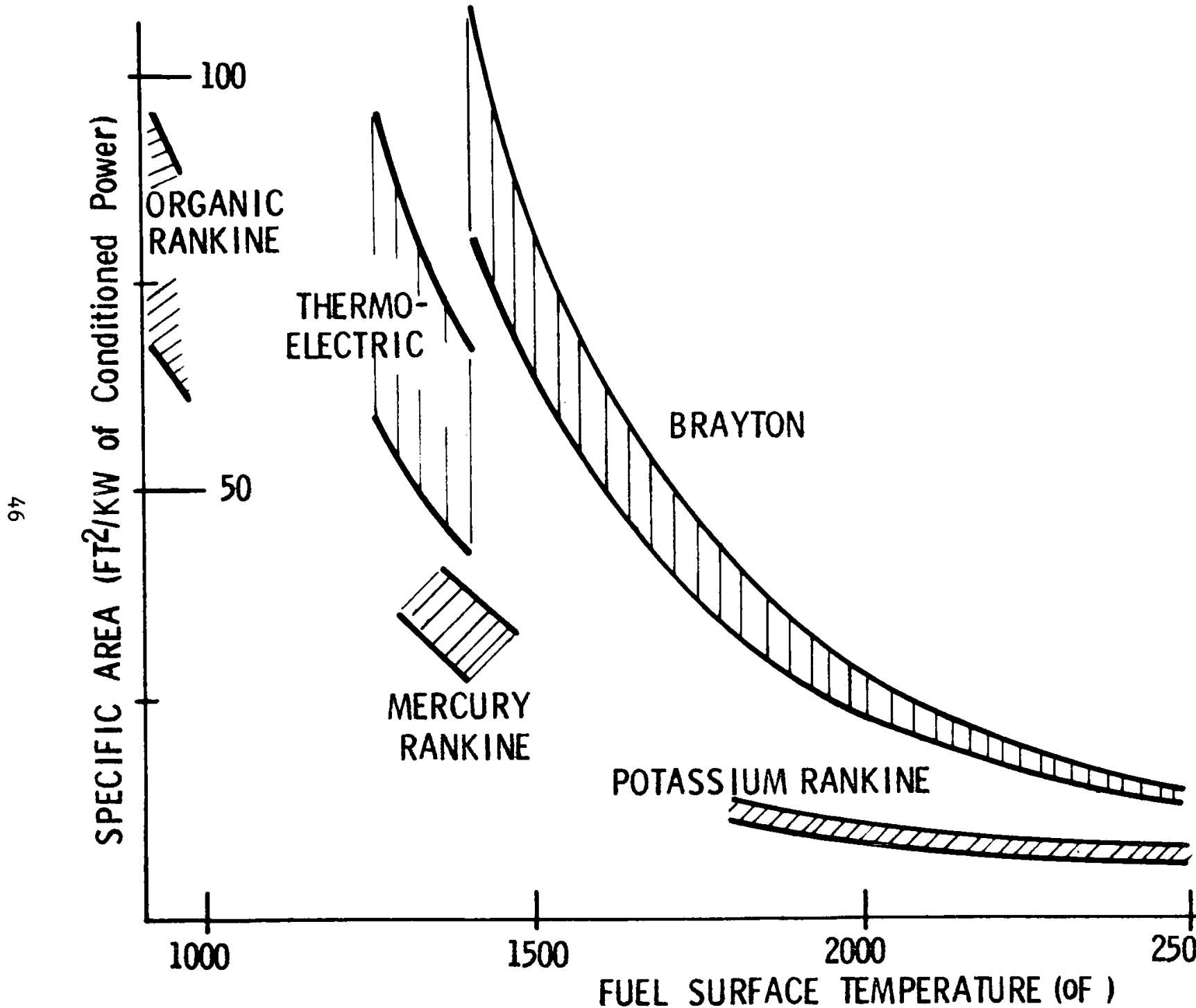

THERMIONIC

27272727272727

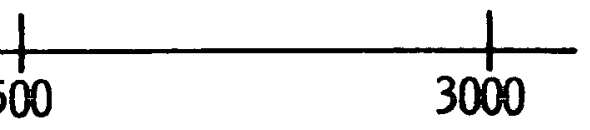

Figure 4

$38 \quad 5-507$ 
1

CORE VOLUME VS. FUEL VOLUME FRACTION

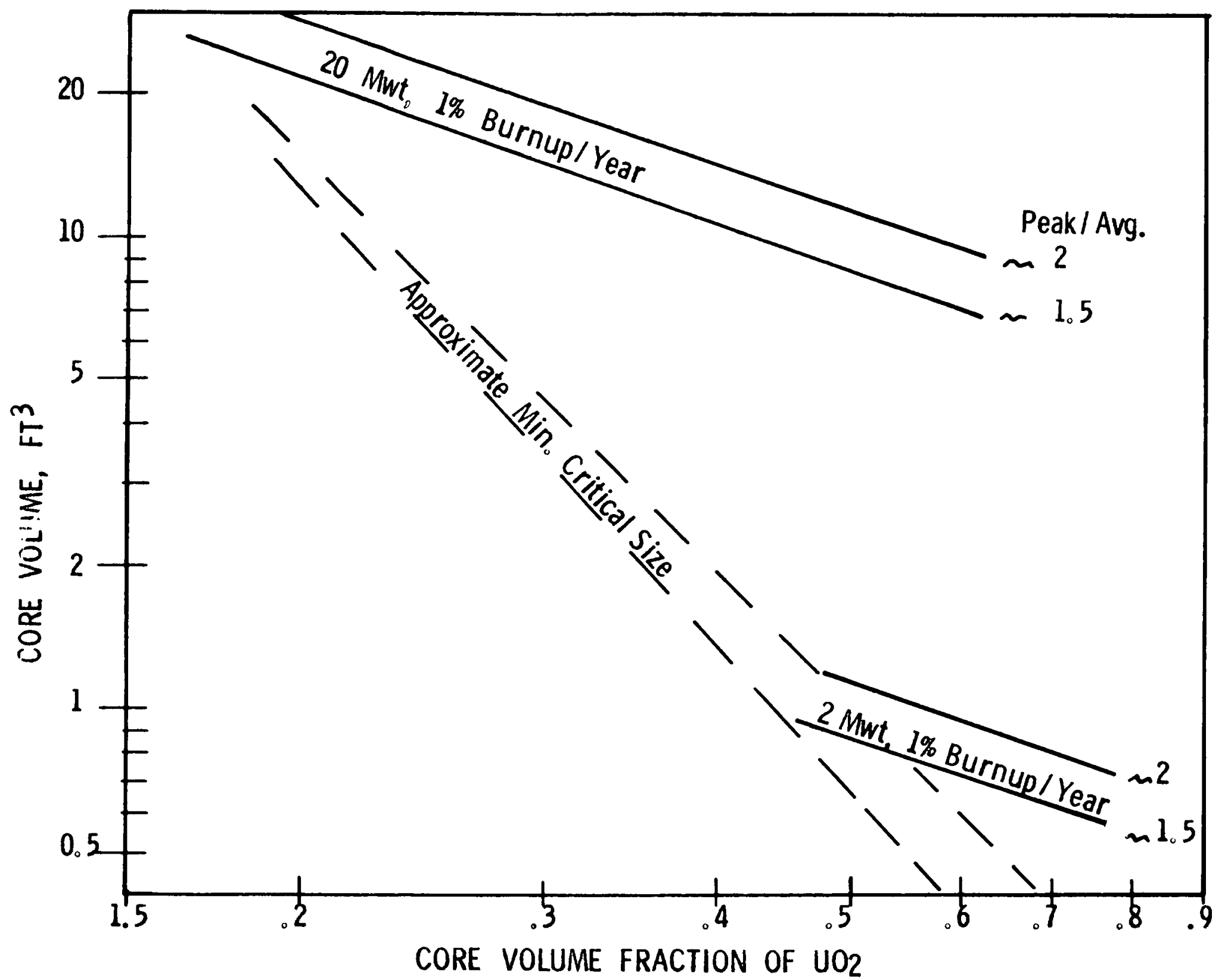

Figure 5 
fast reactors we are planning on for the 50-300 KW range generally fall in one of two places on this graph. For example, a two MWt advanced liquid metal cooled reactor design typically has a fuel volume fraction around 55 to 60 percent, and generally falls on Figure 5 near the intersection of the criticality limit with the one percent burnup per year line for a 2 MWt reactor. In-core thermionic reactors on the other hand, generally have a fuel volume fraction around 30-40 percent and, therefore, tend to have a minimum critical core volume about three to four times larger than an equivalent liquid metal cooled reactor.

The effect of reactor core size on shield weight is illustrated in Figure 6 for two sets of arbitrarily assumed manned shield criteria; i.e., a dose rate of $10 \mathrm{mr} / \mathrm{hr}$ at a separation distance of 100 feet over a dose plant 100 feet in diameter and 30 feet in diameter. ${ }^{5}$ For the core volumes in the two reactor examples discussed above, Figure 6 indicates that the larger diameter, manrated shield for a typical 2 MWt liquid metal cooled reactor would weigh about 17,000 pounds and an equivalent shield for a typical incore thermionic reactor would weigh about 22,000 to 25,000 pounds. In general, the weight of a shadow shield would be expected to be approximately proportional to reactor volume raised to the $1 / 3$ to $2 / 3$ power. For a criticality-limited reactor, therefore, shadow shield weight is approximately inversely proportional to the first or second power of the fuel volume fraction. For burnup limited reactors, shadow shield weight is approximately inversely proportional to fuel volume fraction raised to the $1 / 3$ to $2 / 3$ power.

The two items just discussed, i.e., the shield and the radiator, are typically the heaviest components in a reactor space power system. An estimate of the total shielded weight of various reactor power systems is illustrated in Figure $7.2 *$ The weight advantage of the advanced reactor power plants appears particularly attractive in the power range above 50 to 100 KWe.

\section{THERMIONIC REACTOR PROGRAM}

The current objectives of the thermionic reactor program are to develop and demonstrate a long-lived thermionic fuel element and to demonstrate operation of a thermionic reactor experiment using this fuel element. A typical minimum critical size, $U^{235}$ fueled thermionic reactor might be composed of about 1000 thermionic diodes. These diodes might be arranged as shown schematically on the right hand size of Figure 8. A dozen or so diodes might be wired together in series axially as in the so-called flashlight concept; or the diodes in each layer might be wired together in a parallel-series network as in the so-called unit-cell concept.

The steps in developing thermionic fuel elements are also illustrated in Figure 8. The initial experimental diodes are shown on the left hand side of Figure 8. These experimental diodes are intended to measure the performance of

*In Figure 7 the top of the weight range for each concept is for a manned shadow shield, for $10 \mathrm{mr} / \mathrm{hr}$ over a 75 foot diameter dose plane, 150 feet from the reactor. The bottom of the weight range is for an unmanned shadow shield for $10^{12}$ fast nvt and $10^{6}$ rads of gamma rays over a 20 foot diameter dose plant 100 feet from the reactor. 
SHIELD WEIGHT vS. CORE VOLUME

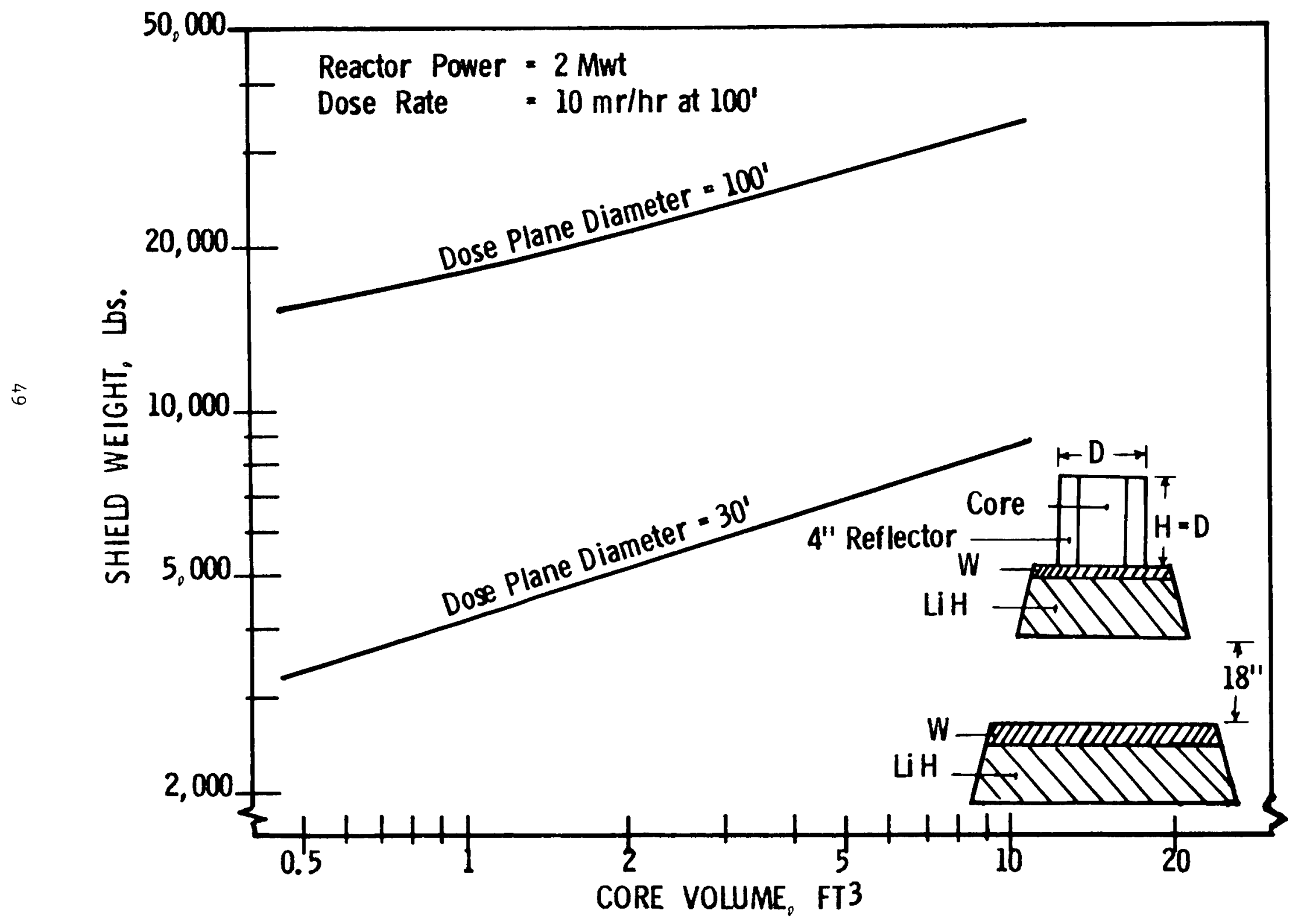




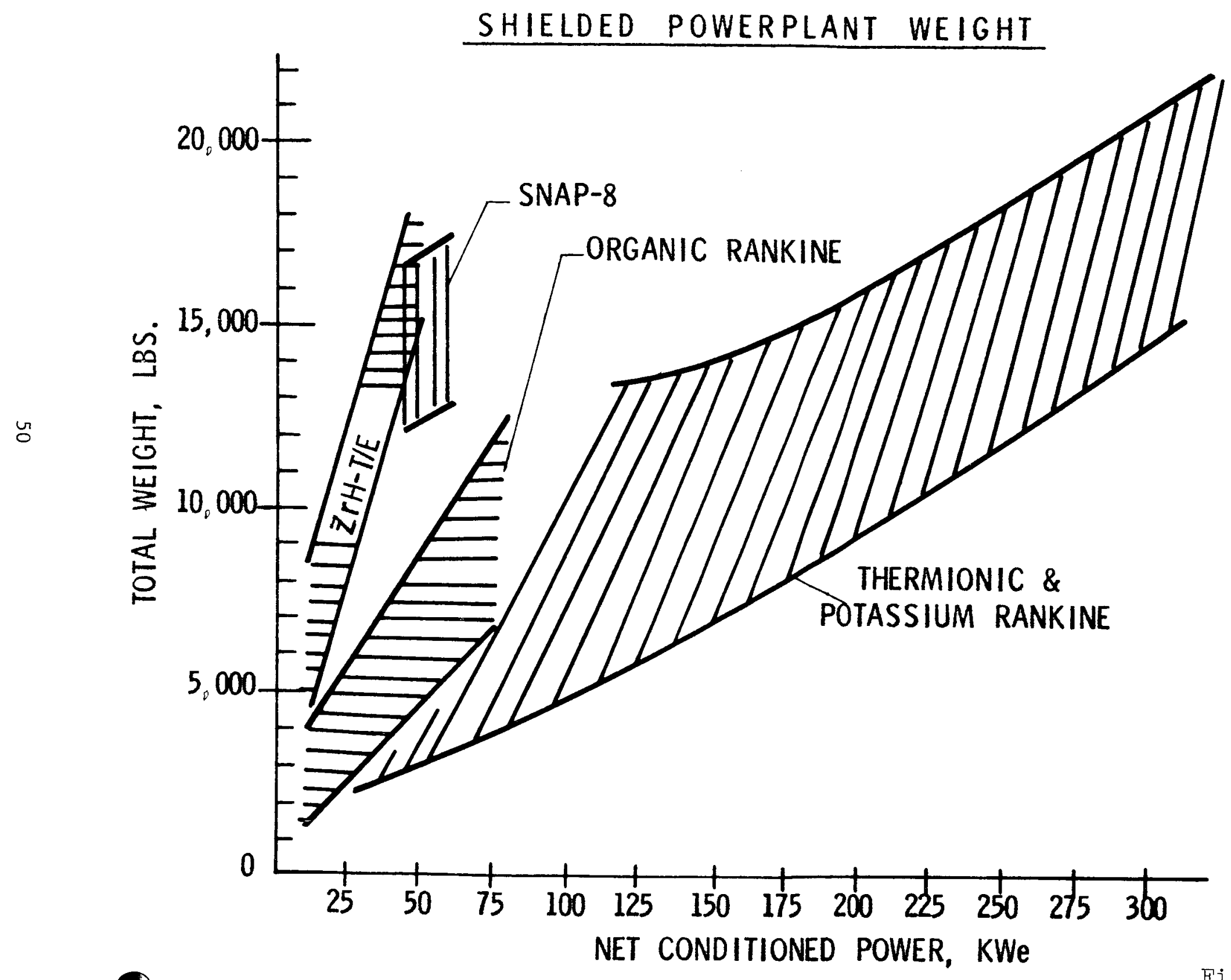

Figure 7

$38 \quad S-506$ 


\section{THERMIONIC REACTOR DEVELOPMENT STEPS}

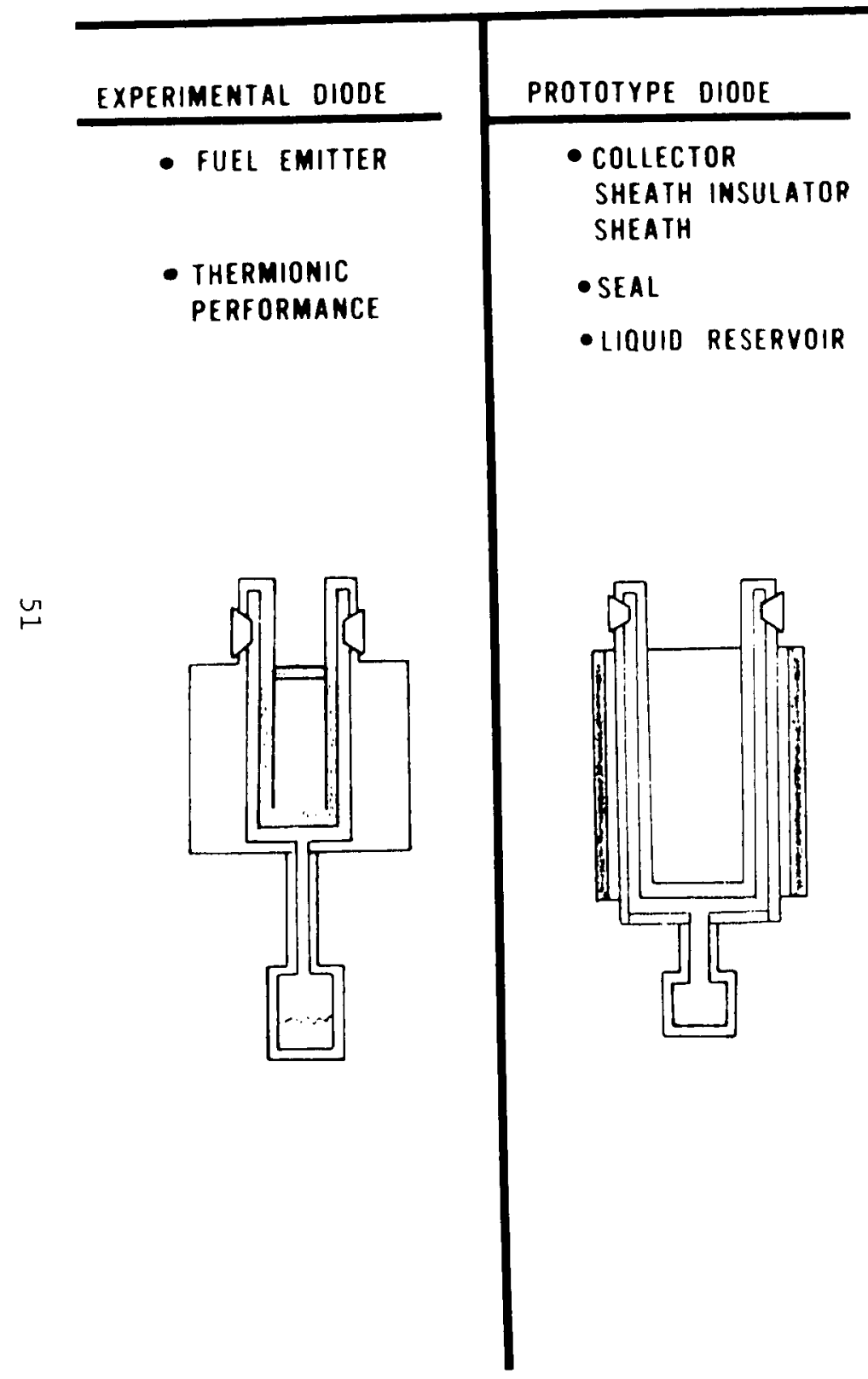

MULTIPLE DIODES

- intercell leads

- fuel element sheath

\& STRUCTURE

- integral cesium reservoir
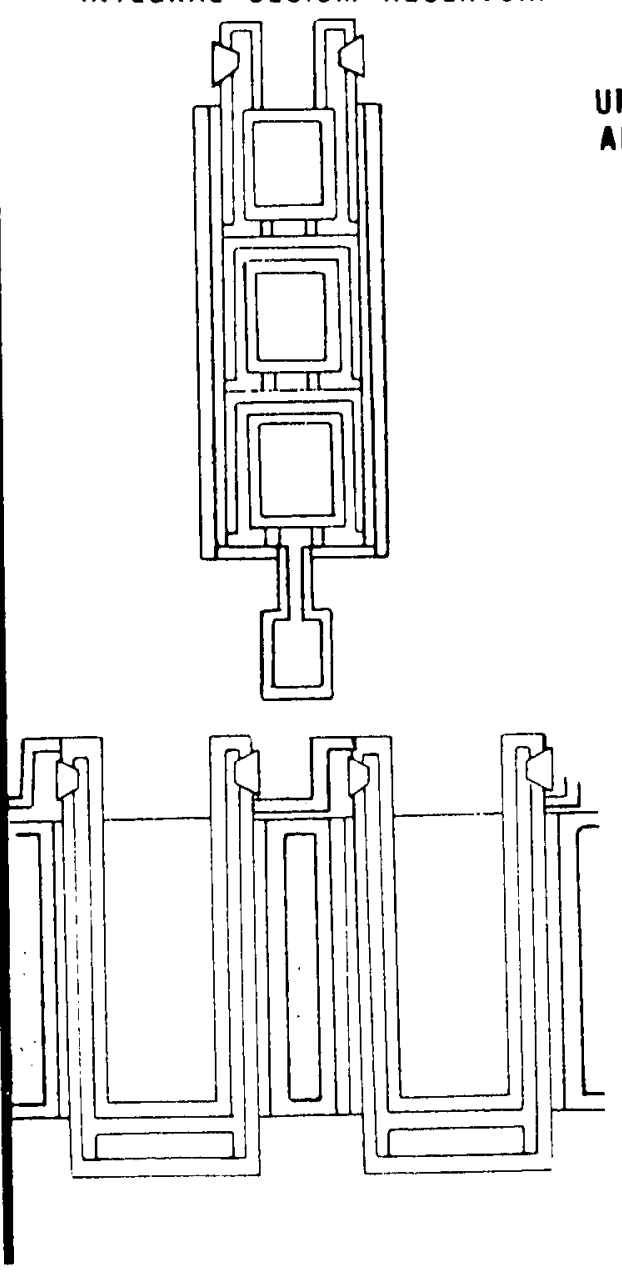

\section{REACTOR EXPERIMENT}

- REACTOR SYSTEM EFFECTS

- control

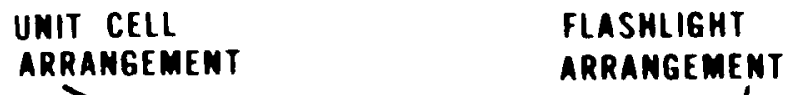

ARRANGEMENT ARRANGEMENT

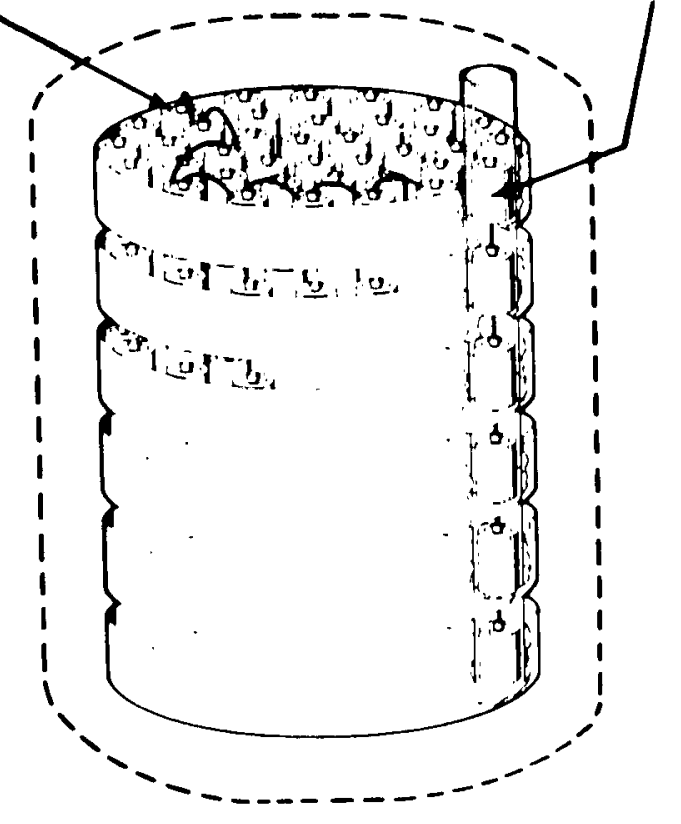

Figure 8 
simple diodes during irradiation and to investigate irradiation and temperature effects on the high temperature fuel and emitter. This work is underway towards its objective of providing in-pile data on satisfactory fuel and emitters to 10,000 hours of operation.

The next steps in developing the fuel element involve adding to the basic diode all of the features which would be required in a reactor fuei element, although the dimensions of these prototype or multiple diodes may differ from the final fuel element design. The prototype diodes include the so-called tri-layer (i.e., a thin collector, the sheath insulator, and the external sheath) and a prototype seal insulator operating at the temperatures expected in the real fuel element. For the flashlight concept, prototype diodes are tested in a three-cell flashlight arrangement which includes the intercell electrical leads.

Most of our diode development effort is now going towards experimental diodes, single prototype cell diodes, and three-cell prototype flashlights. Full length 12cell flashlight and multi-unit cell irradiations are planned in about two years. The experience of General Electric, Gulf General Atomic and Thermo Electron Corporation with in-pile operation of thermionic diodes is summarized in Figure 9. The longest operation of an experimental diode has been about 8000 hours, and prototype diodes have operated about 2000 hours.

Fast neutron irradiation effects on electrical insulators for use in thermionic fuel elements are also being evaluated. An irradiation capsule which the Los Alamos Scientific Laboratory has devised for this purpose may be of interest for other irradiation experiments. This irradiation capsule uses a heat pipe with a gas bulb to maintain a constant temperature on insulator materials irradiated in the EBR-II where instrument leads into the irradiation experiment are impractical. A heat pipe shown schematically in Figure 10, is basically a reflux condenser with a wick on the wall so that capillary action will pump the condensed liquid back to the evaporator section. The heat pipe concept has been applied to the LASL's irradiation capsule design as shown in Figure 11.6 A similar concept is being investigated to regulate temperatures in a uranium nitride fuel irradiation capsule being designed by the Lawrence Radiation Laboratory. ${ }^{4}$

\section{ADVANCED LIQUID METAL COOLED REACTOR PROGRAM}

Some key features of the advanced liquid metal cooled reactor concept are summarized in Figure 12. The reference design is a minimum critical size, fast reactor with a thermal power level of about two MWt. The coolant outlet temperature will be about $2200^{\circ} \mathrm{F}$. The reactor will be fueled with uranium nitride with a ductile tungsten alloy clad. The coolant will be lithium in a refractory metal alloy primary loop.

This reactor can be used with any of several types of power conversion. Potassium Rankine cycle power conversion would be used for a high performance power plant for use with electric propulsion. The reactor can also be used with a Brayton cycle or possibly with high temperature silicon-germanium thermo-electrics. A $1500^{\circ} \mathrm{C}$ heat pipe cooled version of this reactor is also being considered for use with out-of-core thermionics.

The primary emphasis in this program has been in materials development. Lawrence Radiation Laboratory has devised an interesting technique for liquid metal testing which may be applicable to other projects. 


\section{THERMIONIC DIODE IN-PILE EXPERIENCE}

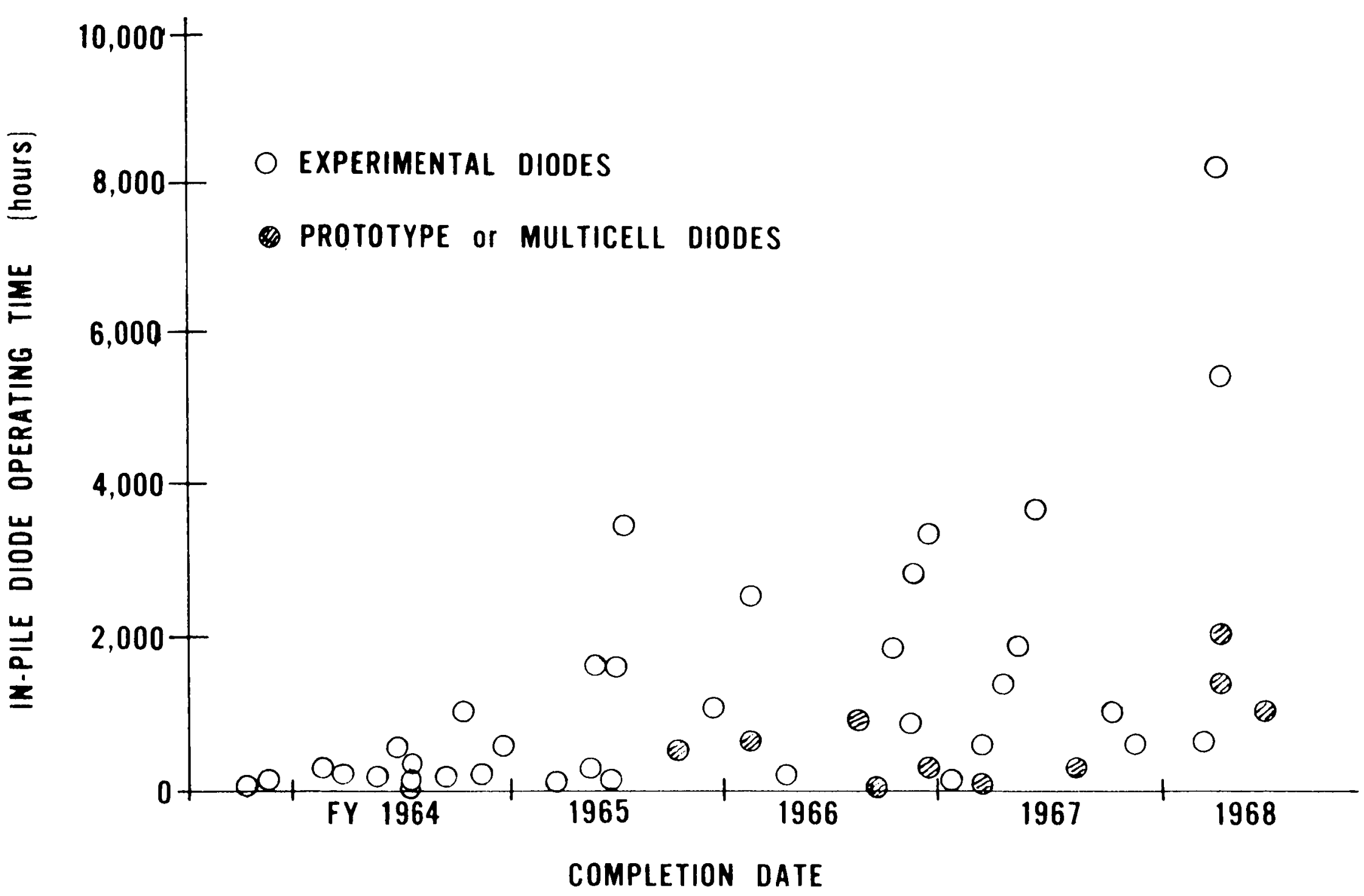




\section{HEAT PIPE}

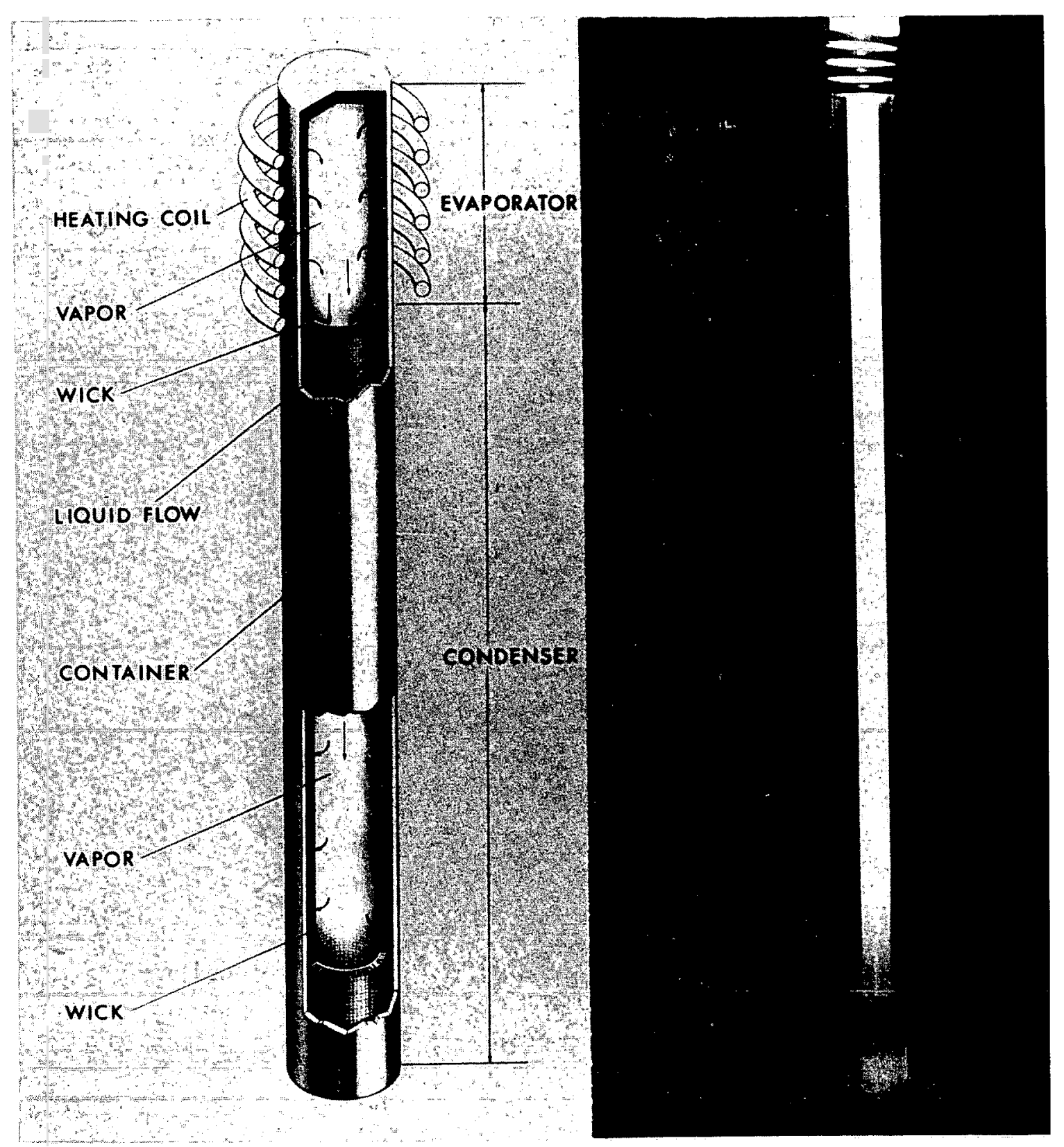

Figure 10 


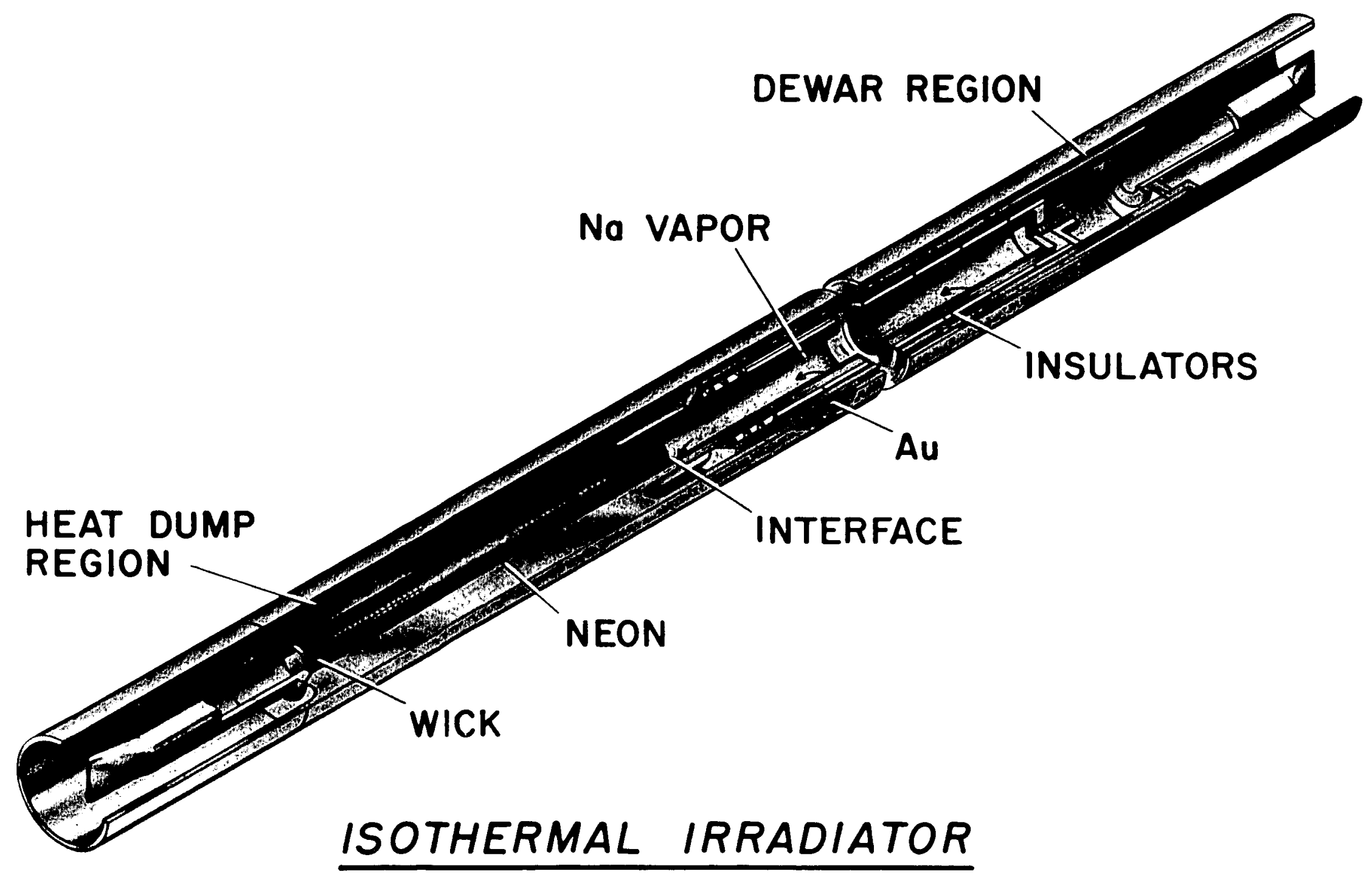




\section{LIQUID-METAL-COOLED REACTOR}

\section{CONCEPT SELECTION STATUS}

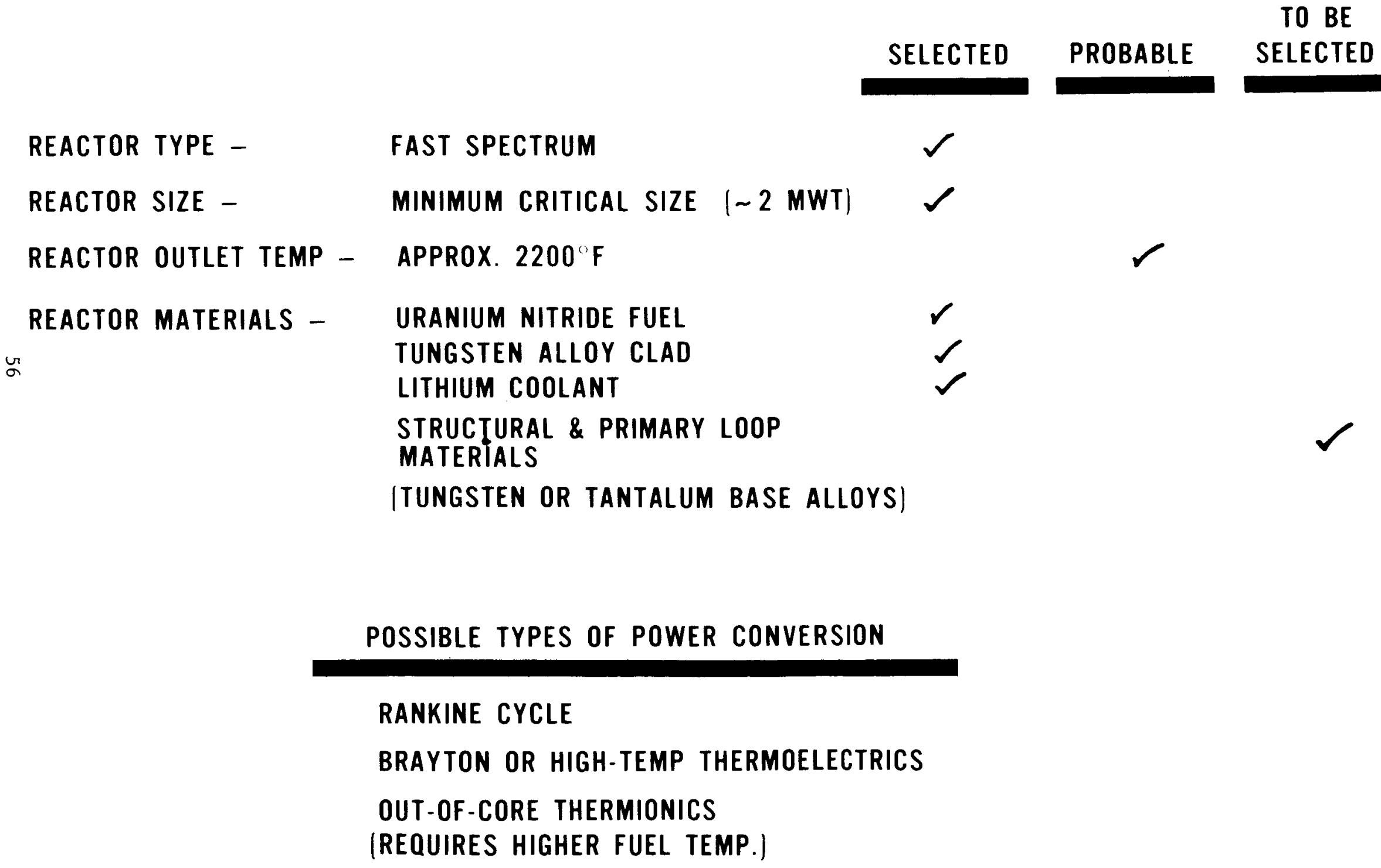


This technique is a pumped capsule for screening tests on mass transfer in flowing liquid metal systems. The concept, shown in Figures 13 and 14 , uses a relatively simple capsule instead of a loop. The basic idea is to place a membrane axially down the middle of the capsule so that flow can go up one side of the capsule and down the other side. One side of the capsule is made into an electromagnetic pump by flowing electricity across one side of the capsule and imposing a magnetic field perpendicular to the electrical current. One end of the capsule is then heated and radiator fins for cooling are attached to the other end. The capsule shown in Figure I 4 was tested in lithium in a tungstenmolybdenum-rhenium alloy at $1400^{\circ} \mathrm{C}$ with a $200^{\circ} \mathrm{C} \Delta \mathrm{T}$ in a turbulent flow for 1000 hours.

SUMMARY

In summary, the space reactor power program is concentrating on three reactors as shown in Figure 15 .

The first is a zirconium hydride reactor for use with either lead-telluride thermoelectric conversion or with dynamic conversion for use in the tens-ofkilowatts range in the $1970^{\prime} \mathrm{s}$.

Two reactor technologies are being developed for high performance, high power systems for the $1980^{\prime} \mathrm{s}$. The two competing advanced concepts are the thermionic reactor and the advanced liquid metal cooled reactor which is intended primarily for use with the potassium Rankine cycle but which has flexibility for use with a variety of power conversion systems.

\section{References}

1. J.D. Lafleur, U.S. Atomic Energy Commission, personal communication, 1968.

2. G.S. Leighton, U.S. Atomic Energy Commission, personal communication, 1967 .

3. L.K. Price, U.S. Atomic Energy Commission, personal communication, 1968.

4. J.W. Hadley, Lawrence Radiation Laboratory, personal communication, 1968.

5. C.P. McCallum, U.S. Atomic Energy Commission, personal communication, 1968.

6. G.M. Grover, Los Alamos Scientific Laboratory, personal communication, 1968 . 


\section{PUMPED CAPGULES}

A SIMPLE METHOD OF DETERMINING CORROSION EFFECTS OF FLOWING LIQUID METALS WITHOUT USING EXPENSIVE, HARD-TO-FABRICATE CIACULATING LOOPB.

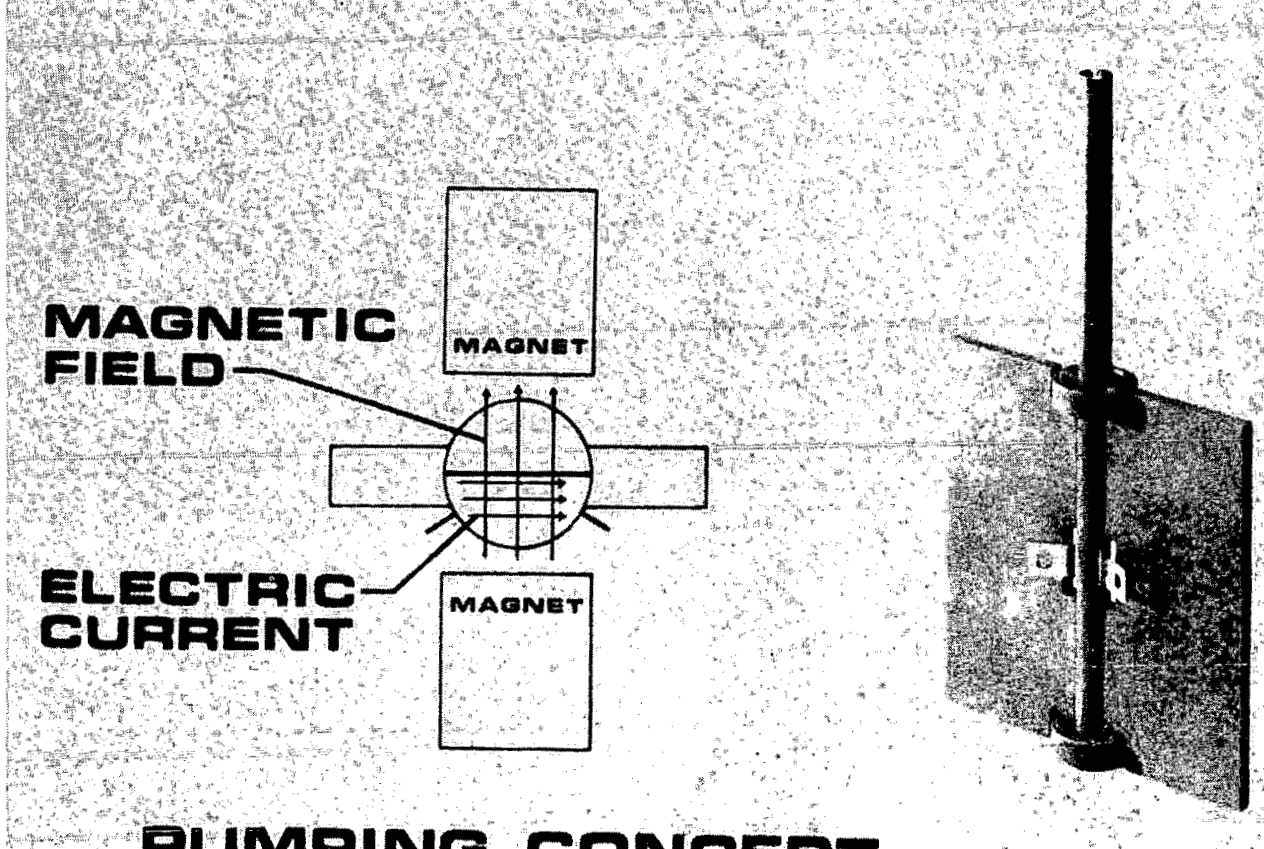

PÜMPING CONCEPT

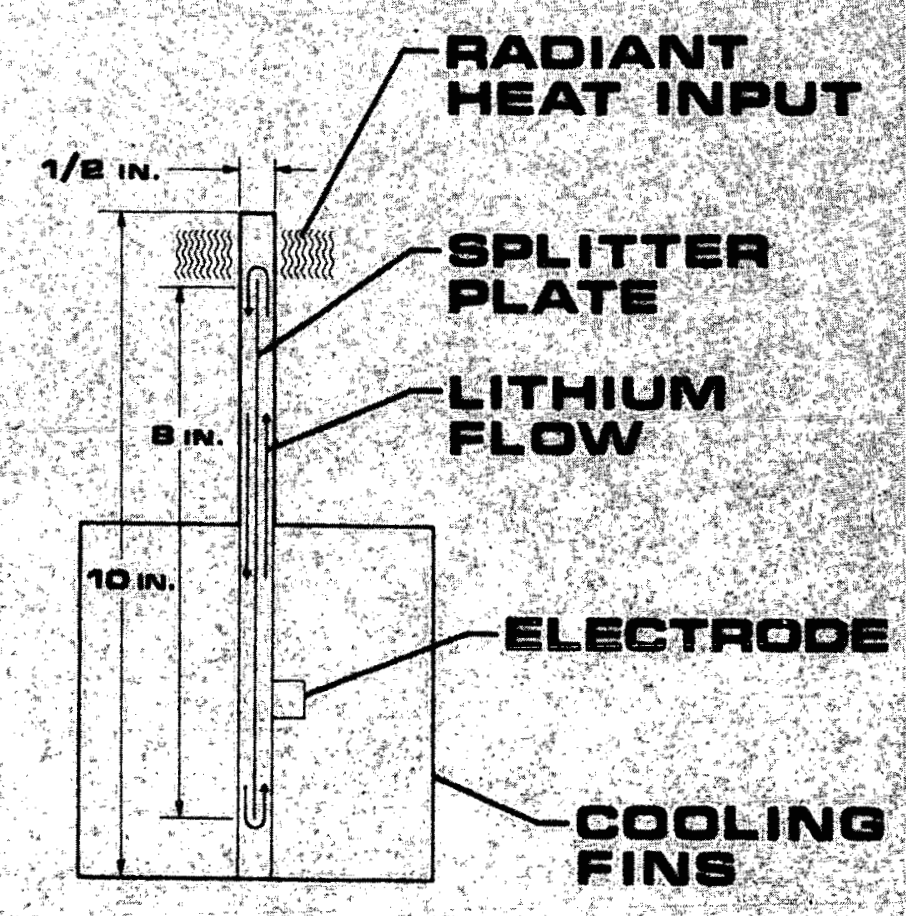



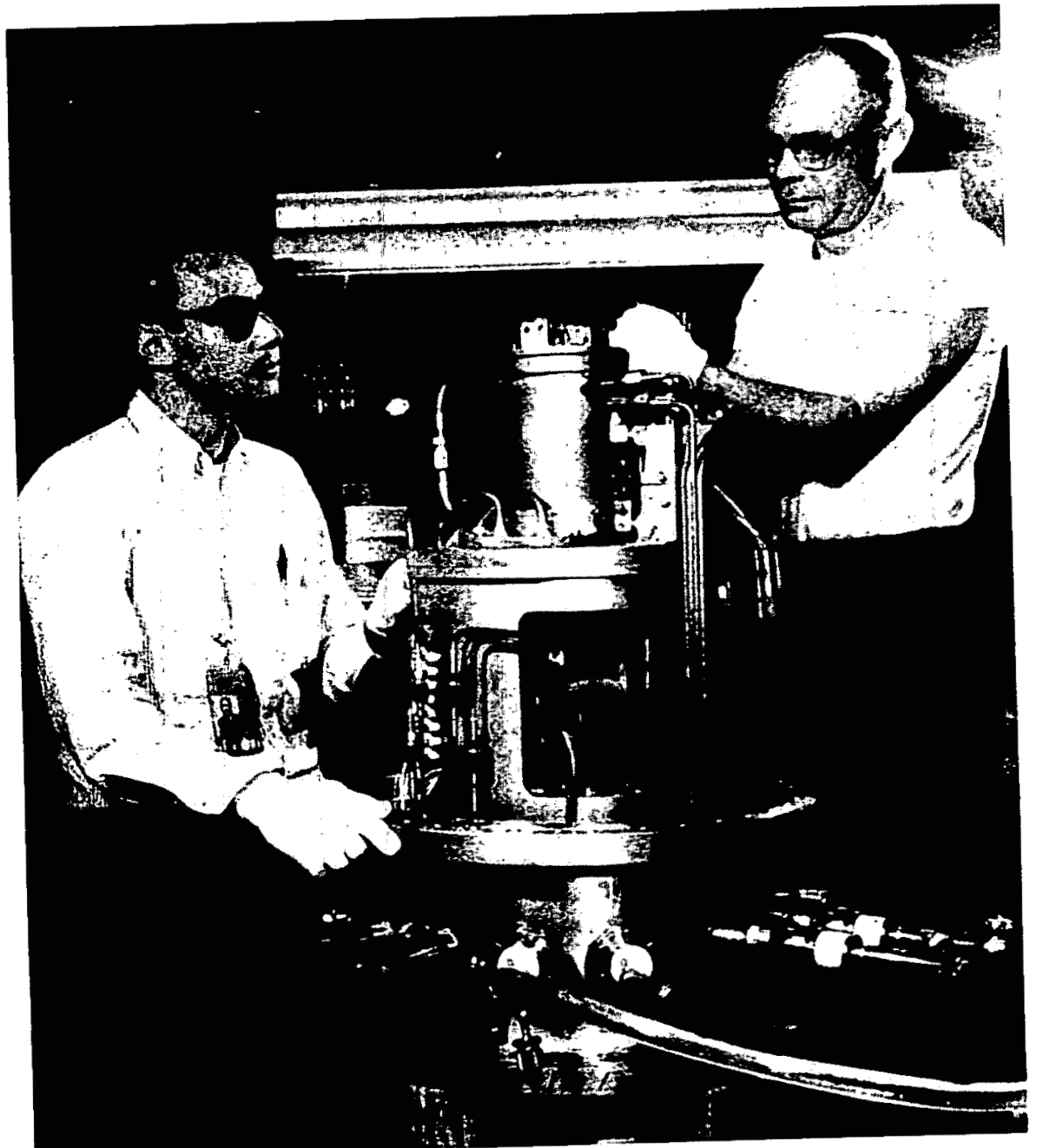

PUMPED CAPSULE TEST ASSEMBLY

Figure 14 


\section{REACTOR SPACE POWER SYSTEMS}

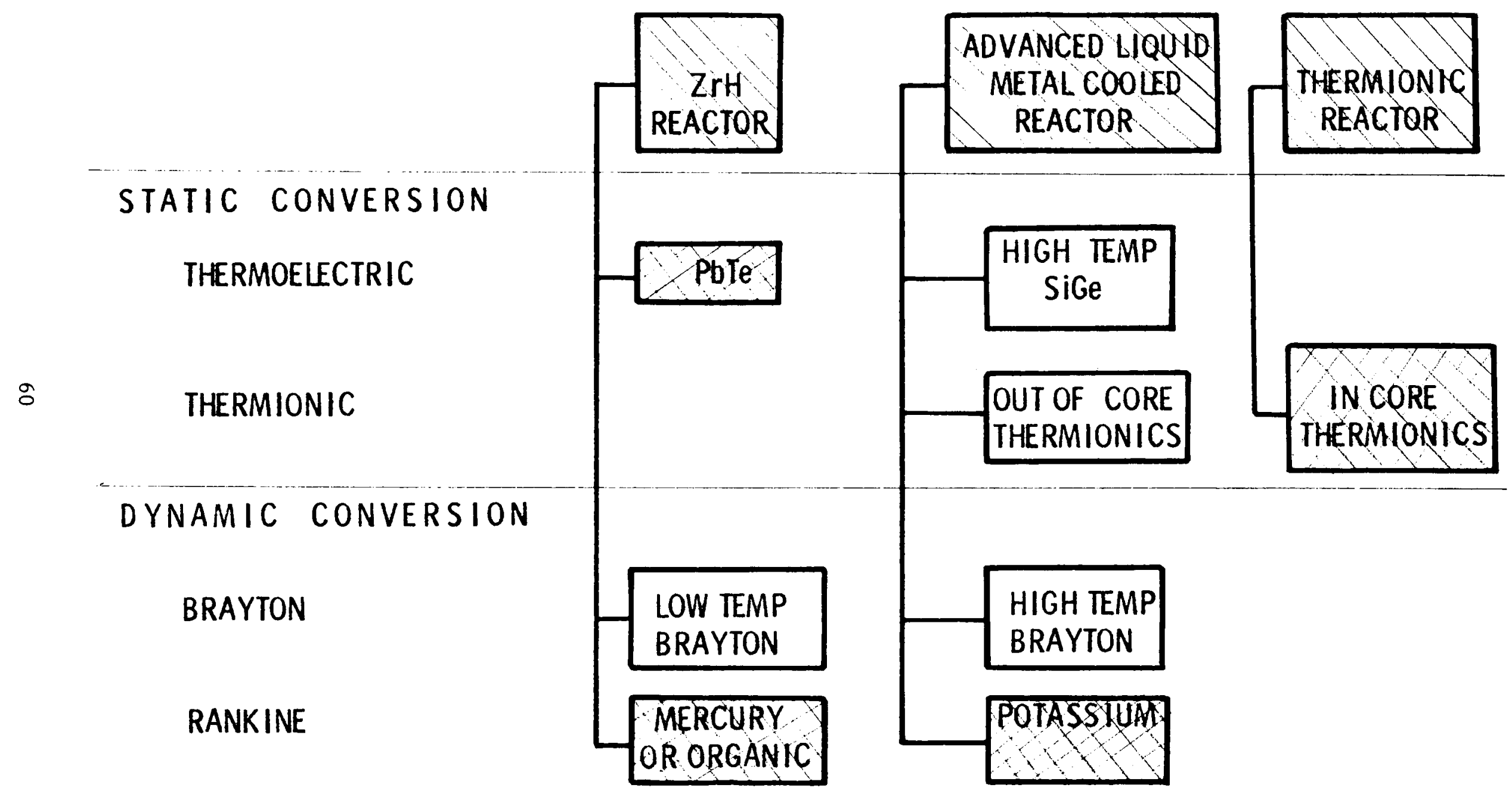

